原 著

\title{
破裂脳動脈瘤に対するバルビタール療法
}

\author{
安藤隆, 坂井昇, 山田弘 \\ 熊谷守雄, 野倉 宏晃, 西村康明 \\ 清 水 言行, 平田 俊 文, 大熊 茂夫米
}

\section{Barbiturate Therapy for Severe Subarachnoid Hemorrhage}

Takashi Ando, M.D., Noboru Sakai, M.D., Hiromu Yamada, M.D., Morio Kumagai, M.D., Hiroaki Nokura, M.D., Yasuaki Nishimura, M.D., Katoyuki Shimizu, M.D.,

Toshifumi Hirata, M.D., and Akio OKuma, M.D.*

Department of Neurosurgery, Gifu University, School of Medicine, and *Department of Neurosurgery, Prefectural Gifu Hospital, Gifu, Japan

Summary : Medical treatment of patients with severe subarachnoid hemorrhage (SAH) and severe vasospasm still poses many problems and the prognosis of these patients is poor. In the present study, we performed barbiturate therapy on 22 cases of severe SAH and 17 cases of severe vasospasm, and obtained good results. One third of the 22 cases of severe SAH treated with barbiturate had an excellent outcome, another $1 / 3$ a good outcome and the last $1 / 3$ a poor otucome. Barbiturate therapy was especially effective with cases accompanied by intracerebral hematoma. In addition, early initiation of the therapy and/or long-term continuation of the therapy for more than two weeks tended to result in a good outcome.

On the other hand, the effectiveness of barbiturate therapy on the 17 cases of severe vasospasm was not necessarily good (the mortality rate reached $41 \%$ ). In these spasm cases, barbiturate therapy was more effective when the therapy was started before the level of consiousness decreased to stupor. Also, it should be kept in mind that the decrease of blood pressure at the start of the barbiturate therapy can possibly aggravate the cerebral ischemia; therefore, the control of blood pressure is critical factor in the effectiveness of the therapy.

The following side effects of the therapy were noted in our series: 15 cases of liver malfunction (38\%), 10 cases of hypotension (26\%), four cases of pneumonia (10\%) and two cases of pancreatitis (5\%). One of the patients complicated with pneumonia died, suggesting that respiratory control to prevent pneumonia is important during the therapy.

\section{はじめに}

重症の破裂脳動脈瘤および脳血管攣縮の治療はいまだ困 難で予後も極めて不良である，我々は，これらの重症例に 対しバルビタール療法を行ってきたので, その有用性, 問 題点などについて検討を加え報告する.
Key words :

- barbiturate therapy

- subarachnoid hemorrhage

- vasospasm

\footnotetext{
岐皁大学 脳神経外科, *県立岐阜病院 脳神経外科
} 
Table 1 Response of barbiturate therapy and outcome

\begin{tabular}{|c|c|c|c|c|c|c|c|c|c|c|c|}
\hline & \multirow{2}{*}{$\begin{array}{c}\text { No. of } \\
\text { cases }\end{array}$} & \multicolumn{4}{|c|}{ Response } & \multicolumn{6}{|c|}{ Outcome } \\
\hline & & $\begin{array}{l}\text { Marked } \\
\text { improve- } \\
\text { ment }\end{array}$ & $\begin{array}{l}\text { Moderate } \\
\text { improve- } \\
\text { ment }\end{array}$ & $\begin{array}{l}\text { Slight } \\
\text { improve- } \\
\text { ment }\end{array}$ & Failure & $\begin{array}{c}\text { Excel- } \\
\text { lent }\end{array}$ & Good & Fair & Poor & Dead & Mortality \\
\hline $\begin{array}{c}\text { A group } \\
\left(\begin{array}{l}\text { severe cases of } \\
\text { ruptured aneurysm }\end{array}\right)\end{array}$ & 22 & $\begin{array}{c}7 \\
(32 \%)\end{array}$ & $\begin{array}{c}7 \\
(32 \%)\end{array}$ & $\begin{array}{c}1 \\
(5 \%)\end{array}$ & $\begin{array}{c}7 \\
(32 \%)\end{array}$ & $\begin{array}{c}3 \\
(14 \%)\end{array}$ & $\begin{array}{c}6 \\
(28 \%)\end{array}$ & $\begin{array}{c}6 \\
(28 \%)\end{array}$ & $\begin{array}{c}0 \\
(0 \%)\end{array}$ & $\begin{array}{c}7 \\
(32 \%)\end{array}$ & $32 \%$ \\
\hline$\left(\begin{array}{c}\text { B group } \\
\text { severe cases of } \\
\text { cerebral vasospasm }\end{array}\right)$ & 17 & $\begin{array}{c}2 \\
(12 \%)\end{array}$ & $\begin{array}{c}5 \\
(30 \%)\end{array}$ & $\begin{array}{c}1 \\
(6 \%)\end{array}$ & $\begin{array}{c}9 \\
(53 \%)\end{array}$ & $\begin{array}{c}5 \\
(30 \%)\end{array}$ & $\begin{array}{c}2 \\
(12 \%)\end{array}$ & $\begin{array}{c}1 \\
(6 \%)\end{array}$ & $\begin{array}{c}2 \\
(12 \%)\end{array}$ & $\begin{array}{c}7 \\
(41 \%)\end{array}$ & $41 \%$ \\
\hline Total & 39 & $\begin{array}{c}9 \\
(23 \%)\end{array}$ & $\begin{array}{c}12 \\
(31 \%)\end{array}$ & $\begin{array}{c}2 \\
(5 \%)\end{array}$ & $\begin{array}{c}16 \\
(41 \%)\end{array}$ & $\begin{array}{c}8 \\
(21 \%)\end{array}$ & $\begin{array}{c}8 \\
(21 \%)\end{array}$ & $\begin{array}{c}7 \\
(18 \%)\end{array}$ & $\begin{array}{c}2 \\
(5 \%)\end{array}$ & $\begin{array}{c}14 \\
(36 \%)\end{array}$ & $36 \%$ \\
\hline
\end{tabular}

ので Hunt \& Kosnik (付帯条項なし)の grade III， 3 例, IV，13例， V， 6 例であり，B 群は脳血管攣縮により意識 レベルの低下, 片麻痺, 瞳孔不同, 除脳硬直などの症状が 出現したものである. なお39例中37例は急性期手術を行っ たが残りの 2 例は，待機手術を予定したが途中で死亡し手 術を行っていない. バルビタール療法は thiopental (Ravonal) または pentobarbital (Nembutal) で導入，維持 は pentobarbital $(2 \sim 4 \mathrm{mg} / \mathrm{kg} / \mathrm{hr})$ を用い血中濃度を $40 \mu \mathrm{g} /$ $\mathrm{m} l$ 前後，脳波での burst \& suppression の出現を基準とし た。呼吸管理は respirator を使用し $\mathrm{PaCO}_{2}$ を $30 \mathrm{mmHg}$ 前 後に保った. 終了時は, CT scan, 頭蓋内圧を参考として 原則として漸減法とした。なお，経過中，瞳孔散大，脳波 の平坦化がみられた11例ではバルビタール療法を途中で中 止した。

\section{結果}

最初にバルビタール療法の効果と, その転帰を述べる. 重症の破裂脳動脈瘤 $\mathrm{A}$ 群 (22例) では著効 7 例 (32\%), 有 効 7 例 (32\%), やや有効 1 例 ( $5 \%$ ), 無効 7 例 (32\%) であ り退院時の転帰は良好が 9 例 (excellent 3 例, good 6 例) と $42 \%$ を占め，死亡は 7 例 (mortality $32 \%)$ であった。一 方，重症の脳血管攣縮の B 群 (17例) では著効 2 例 (12\%), 有効 5 例 (30\%), やや有効 1 例 (6\%), 無効 9 例 (53\%) で あり，転帰は良好 7 例 (excellent 5 例， good 2 例）と $42 \%$ を占め不良は 3 例 (fair 1 例, poor 2 例) で18\%, 死亡は 7 例 (mortality 41\%) であった (Table 1)。これらの結果を要 約すると重症の破裂脳動脈瘤では $1 / 3$ が著効, 1/3が有効, 残りの $1 / 3$ が無効であり，重症の脳血管攣縮では約半数が 無効であった。これらの結果は必ずしも良好とは言えない が本療法を最終手段として用いたことをさしひけば，ほほ 満足すべき結果であると考えている.

\section{1. 脳動脈瘤の部位および年齢と予後について}

動脈瘤の部位と予後については特に有意差はみられなか ったが，年齢については B 群では61歳以上の高齢者 7 例 では poor 2 例, $\operatorname{dead} 4$ 例と予後不良であった(Table 2 ).

\section{2. 神経学的 grade, 意識レベルと予後について}

神経学的 grade が高く, 意識レベルが重篤なほど, 予後 は不良ではあるが A 群については grade IV の13例中 7 例 (excellent 2例, good 5例) が良好であり grade Vでも6 例 中 3 例を救命しえた。 また，意識レベルについてはB 群 では意識が而 2 に陥ってからバルビタール療法を開始した ものは全例死亡したが，意識レベルの低下が軽度な時点で 開始したものほど予後も良好であった(Table 3).

\section{3. 入院時の CT 所見と予後について}

CT 上のクモ膜下出血の程度については，我々の clot score 表示分類 ${ }^{19)}$ に従った。すなわち20点以上はクモ膜下 血腫も厚く, 特に26点以上は重症例を示す. 全般的にみる と clot score が高いほど，転帰も不良であるがB 群では clot score が高くても良好例が一部にみられた. 脳内血腫 の合併が13例 (前頭葉に 3 例，側頭葉に10例)にみられたが うち死亡はわずか 3 例のみで他の 10 例は救命しえ, 転帰も excellent 2 例, good 4 例, fair 4 例となっている (Table 4).

\section{4. バルビタール療法の開始時期, 期間と予後について}

バルビタール療法の開始時期は $\mathrm{A}$ 群ではクモ膜下出血 の急性期すなわち術前, 術中, 術後より開始し, B 群では クモ膜下出血後 $4 \sim 16$ 日目 (発症平均 7.8 日目) より開始し た。期間は $\mathrm{A}$ 群では平均13.2日間， B 群では6.4日であっ た。結果はA 群では早期に開始したもの，すなわち術前 より開始したものほど良好であり，期間についても 2 週間 以上の長期間施行例ほど明らかに良好例が多くみられた (Table 5). 
Table 2 Correlation of site of aneurysm, age and outcome

\begin{tabular}{|c|c|c|c|c|c|c|c|c|c|c|c|c|}
\hline & \multicolumn{6}{|c|}{ A group } & \multicolumn{6}{|c|}{ B group } \\
\hline & $\begin{array}{c}\text { No. of } \\
\text { cases }\end{array}$ & $\begin{array}{c}\text { Excel- } \\
\text { lent }\end{array}$ & Good & Fair & Poor & Dead & $\begin{array}{c}\text { No. of } \\
\text { cases }\end{array}$ & $\begin{array}{l}\text { Excel- } \\
\text { lent }\end{array}$ & Good & Fair & Poor & Dead \\
\hline $\begin{array}{c}\text { Site of aneurysm } \\
\text { Acom }\end{array}$ & 4 & & 1 & 1 & & 2 & 9 & 3 & 1 & & 1 & 4 \\
\hline MCA & 8 & 2 & 3 & 2 & & 1 & 1 & & & & & 1 \\
\hline ICPC & 2 & & 1 & & & 1 & 3 & 1 & & 1 & 1 & \\
\hline multiple & 6 & & 1 & 2 & & 3 & 2 & & & & & 2 \\
\hline others & 2 & 1 & & 1 & & & 2 & 1 & 1 & & & \\
\hline Age & 1 & & 1 & & & & 2 & 2 & & & & \\
\hline $41 \sim 50$ & 3 & & 2 & 1 & & & 4 & 2 & 1 & & & 1 \\
\hline $51 \sim 60$ & 13 & 3 & 2 & 2 & & 6 & 4 & 1 & & 1 & & 2 \\
\hline $61 \sim 70$ & 3 & & & 2 & & 1 & 4 & & 1 & & 2 & 1 \\
\hline $71 \sim$ & 2 & & 1 & 1 & & & 3 & & & & & 3 \\
\hline
\end{tabular}

Table 3 Correlation of Hunt \& Kosnik's grade, consciousness level and outcome

\begin{tabular}{|c|c|c|c|c|c|c|c|c|c|c|c|c|}
\hline & \multicolumn{6}{|c|}{ A group } & \multicolumn{6}{|c|}{ B group } \\
\hline & $\begin{array}{c}\text { No. of } \\
\text { cases }\end{array}$ & $\begin{array}{c}\text { Excel- } \\
\text { lent }\end{array}$ & Good & Fair & Poor & Dead & $\begin{array}{c}\text { No. of } \\
\text { cases }\end{array}$ & $\begin{array}{c}\text { Excel- } \\
\text { lent }\end{array}$ & Good & Fair & Poor & Dead \\
\hline $\begin{array}{c}\text { Hunt \& Kosnik* } \\
\text { (grade) } \\
\text { I }\end{array}$ & & & & & & & 1 & & & & & 1 \\
\hline II & & & & & & & 6 & 3 & & & 2 & 1 \\
\hline III & 3 & 1 & & 1 & & 1 & 8 & 2 & 2 & & & 4 \\
\hline IV & 13 & 2 & 5 & 3 & & 3 & 2 & & & 1 & & 1 \\
\hline V & 6 & & 1 & 2 & & 3 & & & & & & \\
\hline $\begin{array}{r}\text { Level of consciousi } \\
\qquad \begin{array}{r}\text { (JCS) } \\
(3-3-9) \\
0 \sim \mathrm{I}_{3}\end{array}\end{array}$ & 2 & 1 & & 1 & & & 2 & 2 & & & & \\
\hline $\mathrm{II}_{1} \sim \mathrm{II}_{2}$ & 3 & & 1 & 1 & & 1 & 2 & 2 & & & & \\
\hline $\mathrm{II}_{3}$ & 2 & 1 & 1 & & & & 3 & & & & 2 & 1 \\
\hline $\mathrm{III}_{1}$ & 6 & 1 & 3 & 1 & & 1 & 6 & 1 & 2 & 1 & & 2 \\
\hline $\mathrm{III}_{2}$ & 6 & & 1 & 3 & & 2 & 4 & & & & & 4 \\
\hline $\mathrm{III}_{3}$ & 3 & & & & & 3 & & & & & & \\
\hline
\end{tabular}

* Grades of preoperative severity ** Level of consiousness before barbiturate therapy 
Table 4 Correlation of CT findings on admission and outcome

\begin{tabular}{|c|c|c|c|c|c|c|c|c|c|c|c|c|}
\hline & \multicolumn{6}{|c|}{ A group } & \multicolumn{6}{|c|}{ B group } \\
\hline & $\begin{array}{c}\text { No. of } \\
\text { cases }\end{array}$ & $\begin{array}{c}\text { Excel- } \\
\text { lent }\end{array}$ & Good & Fair & Poor & Dead & $\begin{array}{c}\text { No. of } \\
\text { cases }\end{array}$ & $\begin{array}{l}\text { Excel- } \\
\text { lent }\end{array}$ & Good & Fair & Poor & Dead \\
\hline $\begin{array}{c}\text { Clot score* } \\
\quad 0 \sim 10\end{array}$ & 1 & & & & & 1 & & & & & & \\
\hline $11 \sim 15$ & 1 & & & & & 1 & & & & & & \\
\hline $16 \sim 20$ & 9 & 2 & 4 & 3 & & & 7 & 1 & 1 & & 1 & 4 \\
\hline $21 \sim 25$ & 6 & & 1 & 3 & & 2 & 4 & 2 & & & 1 & 1 \\
\hline $26 \sim 30$ & 5 & 1 & 1 & & & 3 & 6 & 2 & 1 & 1 & & 2 \\
\hline $\begin{array}{c}\text { Intracerebral } \\
\text { hematoma } \\
\text { present }\end{array}$ & 13 & 2 & 4 & 4 & & 3 & 6 & 1 & 1 & & 1 & 3 \\
\hline absent & 9 & 1 & 2 & 2 & & 4 & 11 & 4 & 1 & 1 & 1 & 4 \\
\hline
\end{tabular}

*According to our classification of clot score

Table 5 Correlation of timing, duration of the therapy and outcome in A group

\begin{tabular}{c|c|ccccc}
\hline & $\begin{array}{c}\text { No. of } \\
\text { cases }\end{array}$ & Excellent & Good & Fair & Poor & Dead \\
\hline $\begin{array}{c}\text { Timing of the therapy } \\
\text { Before operation }\end{array}$ & 8 & 2 & 3 & 2 & \\
$\begin{array}{l}\text { During operation } \\
\text { After operation }\end{array}$ & 8 & & 1 & 1 & 1 \\
$\quad$ No operation & 2 & 1 & 2 & 3 & 2 \\
\hline $\begin{array}{c}\text { Duration of the } \\
\text { therapy (days) }\end{array}$ & & & & & \\
$\quad 5$ & 2 & & & & \\
$6 \sim 10$ & 6 & 1 & 1 & & 2 \\
$11 \sim 15$ & 1 & & & & \\
$16 \sim$ & 13 & 2 & 5 & 6 & \\
\hline
\end{tabular}

\section{5. 副作用について (治療期間との関係)}

副作用としては肝機能障害15例，低血圧10例，肺炎 4 例， 膵炎 2 例, 出血性脳梗塞 2 例, 徐脈 1 例, 気胸 1 例がみら れた。このうち肝機能障害が最も多く $38 \%$ を占めたが長期 施行例ほど，その発生率は高かった。しかしながらいずれ も軽度でそのための中止例はなくバルビタール療法中止後, すみやかに回復した．肺炎は 4 例と少なかったがこれは， 胸部レントゲンで肺炎所見を呈するもののみに限ったこと によるもので軽度の肺炎は，かなりの頻度でみられており 肺炎対策は大切である. それには頻繁な喀痰吸引を行うこ と，さらに我々は対策として喀痰の吸引困難例に対しては 気管支鏡使用による喀痰除去を行っている．膵炎と思われ る 2 例は, いずれもアミラーゼ值が正常の 2 〜倍に上昇 していたがバルビタール療法の終了とともに正常化した。 合併症による死亡は 2 例にみられ 1 例は肺炎で他の 1 例は
バルビタール療法終了後に生じた出血性脳梗塞によった (Table 6).

\section{症例}

以下，代表症例を 4 例，呈示する.

〈症例 1〉 A 群の代表例であるが67歳女性. Acom と ICopth.の多発性動脈瘤で入院時 Hunt \& Kosnik の grade IV, 意識は $\mathrm{II}_{3}$ であった. CTにて脳内血腫, 脳室内穿破を伴 う強度のクモ膜下出血がみられた. 術前よりバルビタール 療法を開始，10日目より漸減し15日目に終了した。意識レ ベルも徐々に回復, CT でも梗塞像の出現もなく 2 か月後 には ADL 2となった(Fig. 1).

〈症例 2〉 B 群の代表例である. 68歳男性. Acom の動脈 瘤で入院時 Hunt \& Kosnik grade IIIであった. 術後経過 
Table 6 Side effect in correlation to the duration of the therapy

\begin{tabular}{|c|c|c|c|c|c|c|c|c|c|c|}
\hline \multirow{2}{*}{ Side effect } & \multicolumn{5}{|c|}{ A group: duration (days) } & \multicolumn{4}{|c|}{ B group: duration (days) } & \multirow{2}{*}{ Total } \\
\hline & $\begin{array}{c}\text { No. of } \\
\text { cases }\end{array}$ & $\sim 5$ & $6 \sim 10$ & $11 \sim 15$ & $16 \sim$ & $\begin{array}{c}\text { No. of } \\
\text { cases }\end{array}$ & $\sim 3$ & $4 \sim 7$ & $8 \sim 11$ & \\
\hline liver dysfunction & 12 & & 2 & 1 & 9 & 3 & & & 3 & $15(38 \%)$ \\
\hline hypotension & 5 & 2 & 1 & & 2 & 5 & 2 & 1 & 2 & $10(26 \%)$ \\
\hline pneumonia & 3 & & & $1^{*}$ & 2 & 1 & & 1 & & $4(10 \%)$ \\
\hline $\begin{array}{l}\text { pancreatitis } \\
\text { (amylase } \uparrow \text { ) }\end{array}$ & 1 & & & & 1 & 1 & & & 1 & $2(5 \%)$ \\
\hline bradycardia & 0 & & & & & 1 & & & 1 & $1(3 \%)$ \\
\hline pneumothorax & 1 & & & & 1 & 0 & & & & $1(3 \%)$ \\
\hline $\begin{array}{l}\text { hemorrhagic } \\
\text { infarction }\end{array}$ & 0 & & & & & 2 & & & 2 & $2(5 \%)$ \\
\hline
\end{tabular}

* died of pneumonia

67Y. (F) multiple aneurysms (Acom + IC-opth) [H \& K. IV]
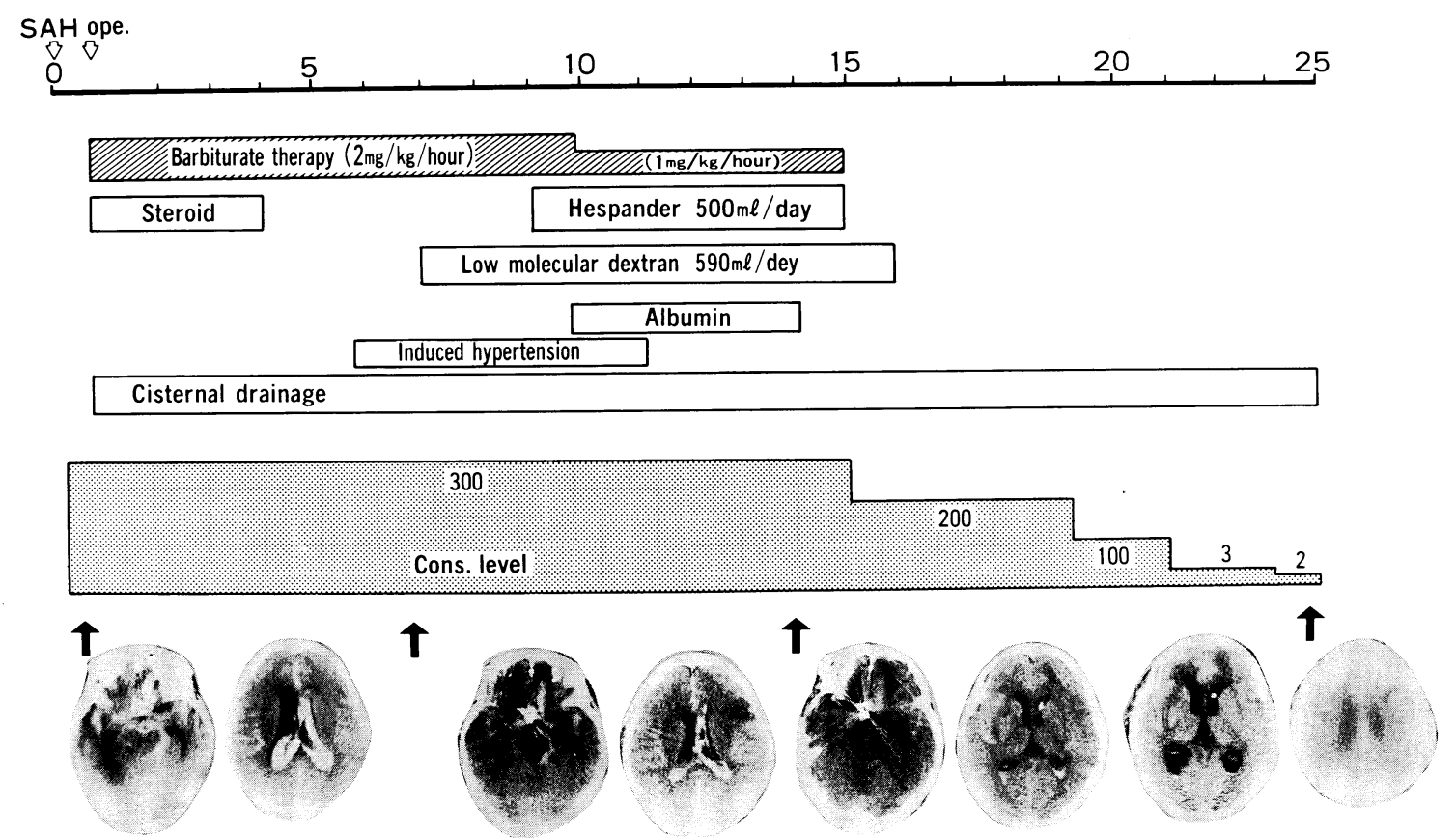

Fig. 1 (Case 1) A presentative case of A group (severe SAH group). Barbiturate therapy was started before operation, continued for 15 days, and resulted in a good outcome.

も良好であったが，発症 9 日目に脳血管攣縮による意識レ ベル低下をきたしIII 1 となり脳血管撮影でも血管攣縮著明 で人工血液製剤の Fluosol-DAの投与とバルビタール療法 を 4 日間行った. 予後も良好で 2 か月後 ADL 2 となった (Fig. 2).

次に結果が不良であった 2 症例を呈示し問題点について 述べる。

〈症例 3〉63歳女性. Acom 動脈瘤で発症 1 日目に手術施 行, 術後経過良好であったが 7 日目に脳血管攣縮により意 374 脳卒中の外科 $17: 1989$
識 II ${ }_{2}$ となら゙ルビタール療法を開始した，導入の際，一 過性であるが，収縮期血圧が $180 \mathrm{mmHg}$ から $110 \mathrm{mmHg} に$ 急激に低下し結果も多発性脳梗塞を残し poorであった。 本例では血圧の低下が悪化の誘因とも考えられバルビター ル療法を行う際には, 血圧の管理には十分注意を払う必要 がある。

〈症例 4 〉 57 歳女性. Acom 動脈瘤で術後経過も良好であ ったが，10日目に意識 $\Pi_{2}$ となりバルビタール療法を開始 し15日目に終了した，経過中12日目の CT で頭頂部に梗塞 


\section{Y. (M) Acom aneurysm (H \& K. III)}
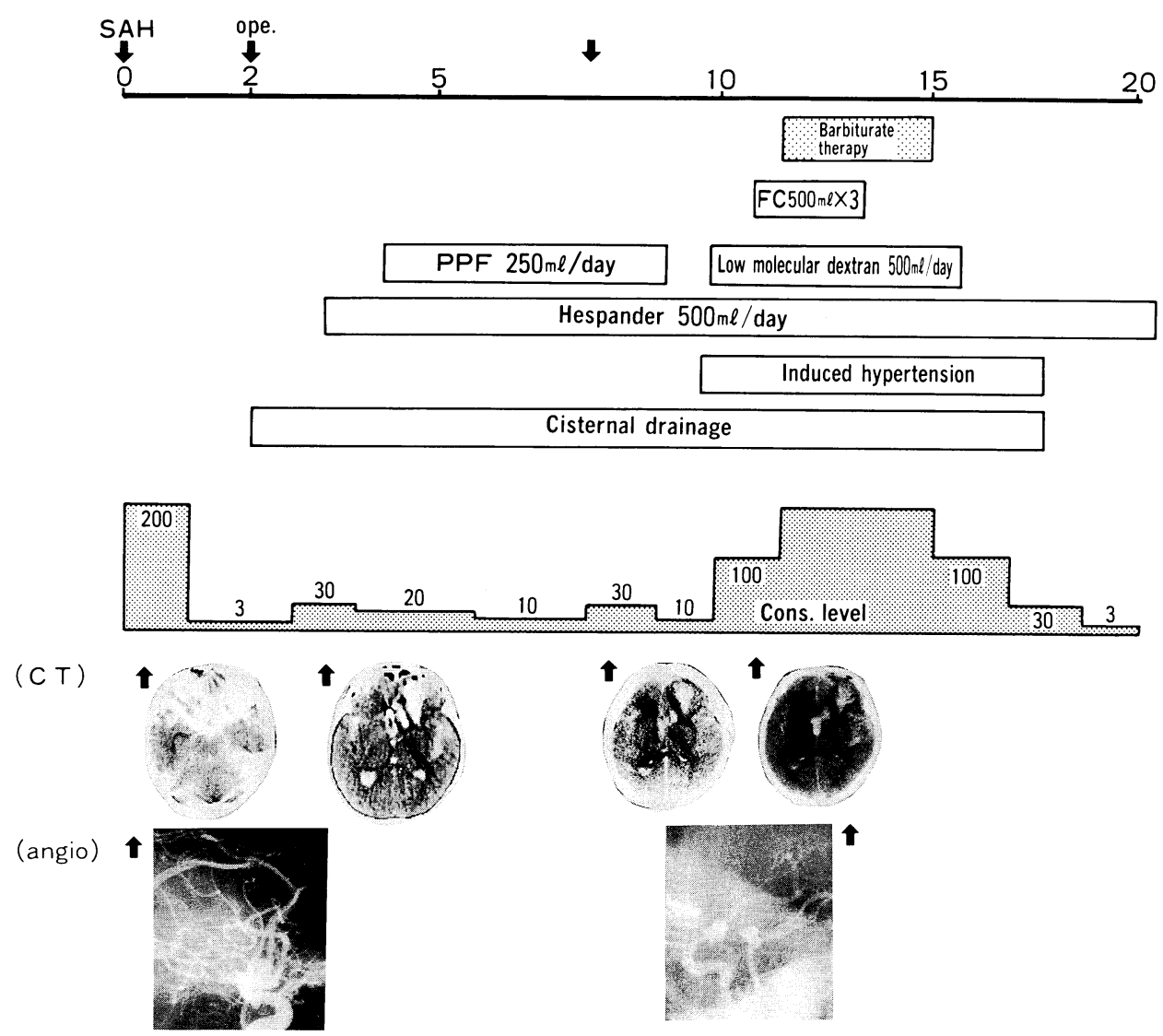

Fig. 2 (Case 2) A presentative case of B group (severe spasm group). On the 9 th day, the level of consciousness came down to stupor due to spasm. Immediately, barbiturate therapy was started and continued for 4 days. The outcome was good.

像の出現をみたがバルビタール終了後, 数時間後にこの梗 塞部に出血性梗塞を併発，脳死状態となり死亡した。本例 ではバルビタール療法中，血圧が低かったために長期に induced hypertension を行ったことが出血性梗塞をきたし た誘因と思われた。なお，本例では ${ }^{123}$ I-IMP SPECTによ る脳血流の経時的測定を行っていたが，16日目には梗塞部 にかなりの血流改善が認められており，この時点で induced hypertension を中止すべきであったと反省している.

\section{考察}

近年, 破裂脳動脈瘤は早期手術が施行されるように早期 搬入例が増加し，それとともに発症早期の重症例も多くみ られるようになった，そのため, 重症の破裂脳動脈瘤の急 性期管理は再破裂防止を含め重要な問題となってきている。 一方, 手術用顕微鏡の導入などの手術手技の進歩により急 性期の脳動脈瘤の手術成績は向上しつつあるが, 重症例の 治療成績は必ずしも満足すべきものではない. 1985年, 西 本らの全日本共同研究 ${ }^{18)}$ によれば急性期手術例の mortal- ity は grade IV 55.2\%, grade V 79.1\%と, きわめて不良 である. 重症の破裂脳動脈瘤の急性期 CT 所見としては, 脳底槽を中心とする高度のクモ膜下出血, diffuse brain swelling, 脳内血腫, 脳室穿破などがみられる. その病態 としては急速かつ高度の頭蓋内圧六進, さらには全脳血流 量の低下による脳浮腫の増大が生ずるとされている(4)8). それゆえ時期を逸することなく早期より頭蓋内圧方進症状 を改善させる積極的治療が必要となってくる. バルビター ル療法は Shapiro ら ${ }^{25)}$ の提唱以来, 脳保護作用に基づき 頭蓋内圧立進に対し臨床応用がなされてきた ${ }^{12) 13)}$. バル ビタールの脳圧降下機序については脳血流量の再配分によ $ろ^{5)}$, 脳動脈血管抵抗の増大による なお定説はない. また，バルビタールには虚血性脳血管障 害における脳保護剤としての臨床効果も認められている 16) 21). 我々は以前よりバルビタール療法を脳動脈瘤の再 破裂防止の一手段として用いてきたが2) 今回は破裂脳動脈 瘤急性期の頭蓋内圧六進症状の改善ならびに脳血管攣縮に 続発する脳虚血に対する脳の保護の面から本療法を行った. 
その結果，重症の破裂脳動脈瘤22例の転帰は excellent 3 例, good 6 例, fair 6 例, dead 7 例 (mortality $32 \%$ )で, そ の効果は $1 / 3$ が著効, 1/3が有効, 残りの $1 / 3$ が無効であっ た．特に脳内血腫の合併が 13 例にみられたが，死亡は 3 例 のみであり脳内血腫合併例に有効であった，従来より脳内 血腫の合併は予後不良因子とされており 1) 3) 10) 15)，その mortality は阿部ら ${ }^{1)}$ は36\%，青柳ら ${ }^{3)}$ は $42 \% ， 川$ 村ら ${ }^{10)}$ は $22 \%$ としている。我々のバルビタール療法を行わなかった 脳内血腫合併例の mortality は中大脳動脈では18例中 9 例 $(50 \%)$, 前大脳動脈瘤では21例中10例 (48\%) ときわめて不 良であった ${ }^{20)}$. 手術により脳内血腫を除去しても，しば しば著明な脳浮腫が血腫部に生じ死亡する例もかなりみら れており, 特に大きな脳内血腫合併例にはバルビタール療 法は有効であろう。破裂脳動脈瘤の急性期におけるバルビ タールの開始時期についてはできるだけ早期に開始したも の，すなわち手術前より開始したものほど良好であり，そ の理由としては脳へルニアをきたす以前, すなわち脳幹機 能が可逆的である時期より行うことが大切であり重症例で は搬入時呼吸障害による anoxia に起因する脳循環障害が 生じており, バルビタール下での呼吸管理は, 脳循環障害 の改善の面からも有効と考えられる. 本療法の施行期間に ついては, 当初 5 日前後の短期間を原則としていたが, 最 近は続発する脳血管攣縮による脳虚血をも乗切る考えのも とで 2 週間以上の長期間施行し良好な結果を得ている。す なわち, 2 週間以上施行の13例では梗塞像の出現はわずか 3 例に認められたのみで，いずれも範囲も小さくこれによ る障害も軽度であった. Smith $5^{28)}$ と Selman $ら^{24)}$ の虚血 実験でも脳虚血後, 早期にバルビタールを開始したものほ ど有効としており Smith ${ }^{28)}$ はイヌの閉塞実験で虚血開 始後15分後に thiopental 投与群では梗塞の発生頻度, 範囲 も有意に減少すると述べている。これらの結果からも, 脳 血管攣縮の発来する以前より開始し攣縮の緩解, 消失する までバルビタール療法を続けることはより合理的であると 考えている.

ところで，脳血管攣縮に対する治療は現在まで種々の方 法が試みられているがいまだ克服されたとは言い難い. 我々も早期手術によるクモ膜下血腫の除去ならびに持続脳 槽ドレナージを原則としてさらに induced hypertension, アルブミン，低分子デキストランによる hypervolemia, $\mathrm{Ca}^{+}{ }^{+}$拮抗剤の投与 ${ }^{7)}$, 抗血小板剂の投与, OKY-046療法 $(\mathrm{OKY})^{27)}$, Vit. C 注入療法 ${ }^{26)}$, Fluosol-DA ${ }^{11)}$ などの併用 療法を現在まで行ってきた。

脳血管攣縮に対するバルビタール療法の報告は Samson $^{22)}$, Kassell ${ }^{9)}$, $\mathrm{Hashi}^{6)}$, 宮城 ${ }^{17)} ら の$ 報告がみられ るがその効果は必ずしも良好とは言えない. 我々も脳血管 攣縮17例に対しバルビタール療法を行ったが, 著効 2 例,
有効 6 例, 残りの 9 例 $(53 \%)$ は無効で諸家の報告のごとく 必ずしも満足すべき結果ではなかった。そ理由として報 告のほとんどは Kassell ら ${ }^{9)}$ の述べるごとく昏睡患者を適 応としており，特に開始時期の遅れが成績も不良にしてい る. 我々の結果も意識が而 2 に陥ってから開始したものは 全例死亡しており, 進行する symptomatic spasm の症例 にはできうる限り早期の開始が望まれる。 また, 高度の symptomatic spasmの場合には，かなりの血流低下の状態 にあり，この時点での開始はかえって脳虚血を助長する危 険性も否定できない. 自験例の 1 例でもバルビタールの導 入時の血圧低下が脳虚血を助長した可能性があり脳血管攣 縮に対する本療法中には血圧の管理には特に注意を払う必 要がある. 最近我々は, 重症の symptomatic spasmに対 しては微小循環の改善剤である人工血液製剤 perfluorochemical (PFC)の併用を行い良好な結果を得ており，今後 は脳血管攣縮に対してはバルビタール療法単独ではなく, これらの薬剂の使用が有用ではなかろうかと考えている.

バルビタール療法の副作用としては血圧低下, 心室性期 外収縮, 肝障害, 肺炎などが報告されている. 我々も, 肝 障害を15例 (38\%) 経験したがいずれもバルビタール療法終 了後, すみやかに回復した. 血圧低下に対してはdopamine hydrochlorideの使用で対処しているが, これに反応 せず血圧低下の著しい症例はいずれも早期に脳死状態に陥 り, 途中でバルビタール療法を中止した. 合併症による死 亡は宮城ら ${ }^{17)}$ は認めていないとしているが, Samson ら ${ }^{22)}$ は 3 例 ( 2 例は血圧低下, 1 例は急性呼吸不全), Kassell $ら^{9)}$ は血胸で 1 例, Hashi $ら^{6)}$ は 2 例 (血圧低下 1 例, 肺水 腫 1 例)にそれぞれ生じたとしている. 我々の 1 例も肺炎 で死亡しており, 肺炎はかなりの頻度でみられており, 特 に長期施行例では肺炎対策が大切となってくる. また, 膵 炎が 2 例みられたが，その因果関係は不明である. 今後, アミラーゼの測定をルチンに行えば，かなりの頻度でみら れるのではないかと注目している.

\section{ま と め}

1. (1)重症の破裂脳動脈瘤 (22例) の予後は excellent 3 例, good 6 例, fair 6 例, dead 7 例 (mortality 32\%) であ った. (2)重症の脳血管攣縮 (17例) の予後は excellent 5 例, good 2 例, fair 1 例, poor 2 例, dead 7 例 (mortality 41\%)であった.

2. 重症の破裂脳動脈瘤での良好例は脳内血腫合併例, 早 期開始例，長期間施行例に多かった.

3. 重症の脳血管攣縮での良好例は意識低下が20１00ま でに開始したものであった. 開始時の血圧低下, 経過 中の出血性梗塞に対する注意が必要である.

4. 副作用としては肝障害15例 (38\%), 低血圧10例 (26\%), 
肺炎 4 例 (10\%), 膵炎 2 例 ( $5 \%$ ) などがみられた. 肺 炎で 1 例死亡しており，肺炎予防に対する呼吸管理が 大切である。

\section{文献}

1）阿部 弘, 都留美都雄, 田代邦雄, ほか : 脳内血腫を伴っ た破裂脳動脈瘤．脳神経外科 5: 527-535, 1977

2）安藤 隆, 郭 泰彦, 平山宏史, ほか：脳動脈瘤再破裂例 の検討一 6 時間以内の超早期破裂とその防止対策. 第 14 回 脳卒中の外科研究会講演集, にゅー万ん社, 東京, 1985, pp 131-137

3）青柳訓夫，早川 勲，井合茂夫ほほか：脳内血腫を伴う脳 動脈瘤の検討一特に手術適応について. 脳神経外科 13 511-518, 1985

4）浅野孝雄：クモ膜下出血に扔ける脳障害. 救急医学 5: 161-168, 1981

5) Bruce DA, Berman WA, Schut L: Cerebrospinal fluid pressure monitoring in children: Physiology, pathology and clinical usefulness. Adv Pediatr 24: 233-290, 1977

6) Hashi K, Tanaka K: Barbiturate coma for severe brain ischemia due to cerebral vasospasm. In: Cerebral Arterial Spasm. Proceedings of the Second International Workshop, edited by Wilkins RH, Williams and Wilkins, Baltimore, 1980, pp 637-645

7）平山宏史，木村隆文，岩間 亨，ほか：脳血管攣縮に対す る塩酸ニカルジピン (YC-93) の効果. 第14回脳卒中の外科 研究会講演集, にゅーろん社, 東京, 1985, pp 272-273

8）池田幸穂，諫山和男，矢嶋浩三，ほか：重症クモ膜下出血 超早期の病態と管理. 第14回日本脳卒中の外科研究会講演 集，にゅーろん社，東京，1985, pp 115-119

9) Kassell NF, Peerless SJ, Drake CG et al: Treatment of ischemic deficits from cerebral vasospasm with high dose barbiturate therapy. Neurosurgery 7: 593-597, 1980

10）川村伸悟, 鈴木明文, 佐山一郎, ほか：脳動脈瘤破裂に伴 う脳内血腫の臨床的意義. Neurol Med Chir (Tokyo) 27: 1158-1166, 1987

11）近藤博昭, 平田俊文, 船越 孝, ほか：脳血管攣縮に対す る Fluosol-DA の効果. 第11回脳卒中の外科研究会講演集, にゅーろん社，東京， 1982, pp 247-251

12) Laurent JP, Lawner P, Simeone FA, et al: Pentobarbital changes compartmental contribution to cerebral blood flow. J Neurosurg 56 : 504-510, 1982

13) Marshall LF, Bruce DA, Bruno L, et al: Role of intracranial pressure monitoring and barbiturate therapy in malignant intracranial hypertension: Case report. J Neurosurg 47:
481-484, 1977

14）長澤史朗，鳴尾好人，米川泰弘，ほか：脳血管攣縮の新し い治療法. Neurol Med Chir (Tokyo) 22: 626-632, 1982

15）長澤史朗，田代 弦，米川泰弘，ほか：破裂中大脳動脈瘤 53例の検討. 脳神経外科 13: 983-989, 1985

16）峰松一夫, 山口武典, 栗山良紘, ほか：ヒト急性期脳梗塞 に対する barbiturate 療法の検討. 脳卒中 5: 286-294, 1983

17）宮城航一：脳保護物質その 1 一脳梗塞防止を目的とした barbiturate 療法. The Mt. Fuji Workshop on CVD 7: 112-118, 1983

18) Nishimoto $A$, Ueta $K$, Onbe $H$, et al: Nationwide cooperative study of intracranial aneurysm surgery in Japan. Stroke 16: 48-52, 1985

19）西村康明，中島利彦，服部達明，ほか：CT上くも膜下腔高 吸収域と脳血管攣縮発現に関する検討一特にその治療との 関係. 第14回日本脳卒中の外科研究会講演集,にゅー万ん 社, 東京, 1985, pp 367-373

20）西村康明, 安藤 隆, 山田 弘, ほか：急性期破裂脳動脈 瘤の予後増悪因子．第14回日本脳神経外科学会中部地方会 抄録, 三重, 1985, p 8

21) Rockoff MA, Marshall LF, Shapiro HM: High-dose barbiturate therapy in humans: A clinical review of 60 patients. Ann Neurol 6: 194-199, 1979

22) Samson DS, Byer CM: Thiopental coma in the treatment of vasospasm induced cerebral ischemia/infarction. In: Cerebral Arterial Spasm: Proceedings of the Second International Workshop, edited by Wilkin RH, Wiliams and Wilkins, Baltimore, 1980, pp 634-636

23）澤田祐介, 高橋道知, 杉本 㑆：Barbiturate 投与による頭 蓋内圧・脳波の変動様式について．神経外傷 3: 95-99, 1977

24) Selman WR, Spetzler RF, Roski RA, et al: Barbiturate coma in focal cerebral ischemia - relationship of protection to timing of therapy. J Neurosurg 56: 685-690, 1982

25) Shapiro HM, Wyre SR, Loeser J: Barbiturate-augmented hypothermia for reduction of persistent intracranial hypertension. J Neurosurg 40: 90-100, 1974

26）敷波 晃, 服部達明, 野倉宏晃, ほか：脳血管攣縮に関す る実験的臨床的研究一とくにVitamin C の効果について. 第11回脳卒中の外科研究会講演集, にゅー万ん社, 東京, 1982, pp 165-170

27）敷波 晃, 山田 弘, 坂井昇, ほか：破裂脳動脈瘤早期 手術後投与に抢ける thromboxane A2 synthetase inhibitor (OKY-046) の脳血管攣縮予防効果の検討. 脳卒中 7: 200209, 1985

28) Smith AL, Hoff JT, Nielsen SL, et al: Barbiturate protection in acute focal cerebral ischemia. Stroke 5: 1-7, 1974 